\title{
A REGIONAL GEOCHRONOLOGICAL STUDY OF LATE PLEISTOCENE PERMAFROST
}

\section{V. KOSTYUKEVICH}

Geochemistry Laboratory, Permafrost Institute, Siberian Branch, Russian Academy of Sciences, Sergelyakh, Yakutsk 677010 Russia

\begin{abstract}
The use of radiocarbon dating in geocryological investigations makes it possible to establish a chronology for permafrost-geological development during the Late Pleistocene. Both global and regional time scales for the formation of Late Pleistocene permafrost have been worked out over the past 15-20 years at the Permafrost Institute of the Siberian Branch of the Russian Academy of Sciences. I present here results from study areas of northwestern Siberia and of North, Central and West Yakutia.
\end{abstract}

\section{INTRODUCTION}

The evolution of natural conditions in northern regions of Russia is closely related to the development of the permafrost zone. The permafrost zone of northern Eurasian Russia existed continuously, with alternating expansions and contractions, during the Pleistocene and Holocene. Postcryogenic structures found in loess layers of the Ukraine show that the southern boundary of the permafrost zone in European Russia reached the Black Sea during the Pleistocene and that the Pleistocene permafrost zone progressed southward and receded northward 3 or 4 times (Danilov 1987a).

The permafrost zone developed as a result of large-scale climate changes. It reached its maximum extent in the Late Pleistocene, following a period during which annual mean temperature in middle and high latitudes decreased by $6-8^{\circ} \mathrm{C}$ compared to the present, in conjunction with drastic global cooling that took place 18-20 ka ago (Velichko 1968). Shilo and Tomirdiaro (1982) associate this drop in temperature with the formation of glaciers and eroded terraces of icy sediments and the largest syngenetic ice veins in the northeastern plains of Russia. Similar deposits up to $30 \mathrm{~m}$ high occur in northwestern Siberia. How climate cooling in the Late Pleistocene influenced the expansion of existing glaciers in the Arctic and Subarctic and the development of the permafrost zone remains in doubt.

Late Pleistocene climate history also includes periods of significant warming. The rise of annual mean temperatures (e.g., during the Holocene, by $4-5^{\circ} \mathrm{C}$, compared to the present) favored displacement of forest vegetation into the tundra zone, vast manifestation of cryogenic processes, and the development of surface glaciation, with overall stability of the permafrost zone, conservation of its areal propagation and considerable decrease in thickness of frozen ground. Warming trends are also reflected in the diversity and forms of permafrost-geological structures in different regions of the permafrost zone.

The use of radiocarbon dating makes it possible to establish a chronology of the development of the permafrost zone during the Late Pleistocene. These investigations, which are in progress at the Geochemistry Laboratory of the Permafrost Institute of the Siberian branch of the Russian Academy of Sciences, are directed toward the formation of both global and regional time scales. The historical development of permafrost-geological processes can be determined through the geochronological study of the syngenetic permafrost with relict ground ice and genetically related alas deposits.

Within a regional context, it is important to study the absolute age of individual cryological and geological structures-perennial frost mounds, perennial icings $\longrightarrow$ of, e.g., subpermafrost waters and 
ground ice. A sizable quantity of ${ }^{14} \mathrm{C}$ data has been obtained for large areas; our research has focused on regional geocryology. It is the purpose of this paper to discuss some of these results.

\section{MeTHODS}

A ${ }^{14} \mathrm{C}$ study involving serial dating of Late Pleistocene permafrost dynamics requires much attention to appropriate techniques. In a geochronological study of this nature, many samples exceed the limit of ${ }^{14} \mathrm{C}$ dating.

To determine the accuracy, reliability and reproducibility of ${ }^{14} \mathrm{C}$ dates, consideration must be given to the wide range of organic material, such as peat, macrofossils, animal bone, reeds, wood and thread-like grass roots, and their preservation in the permafrost, as well as slope processes, resedimentation and techniques of collection, preparation, and analysis of samples. Chemical treatment and benzol syntheses follow the standard techniques of Arslanov and Gromova (1968). Figure 1 illustrates our low-background liquid scintillation counting system. The counting parameters of the instruments make it possible to date samples to 50-55 ka. The counting error for the series is $1.0-2.0 \%$.

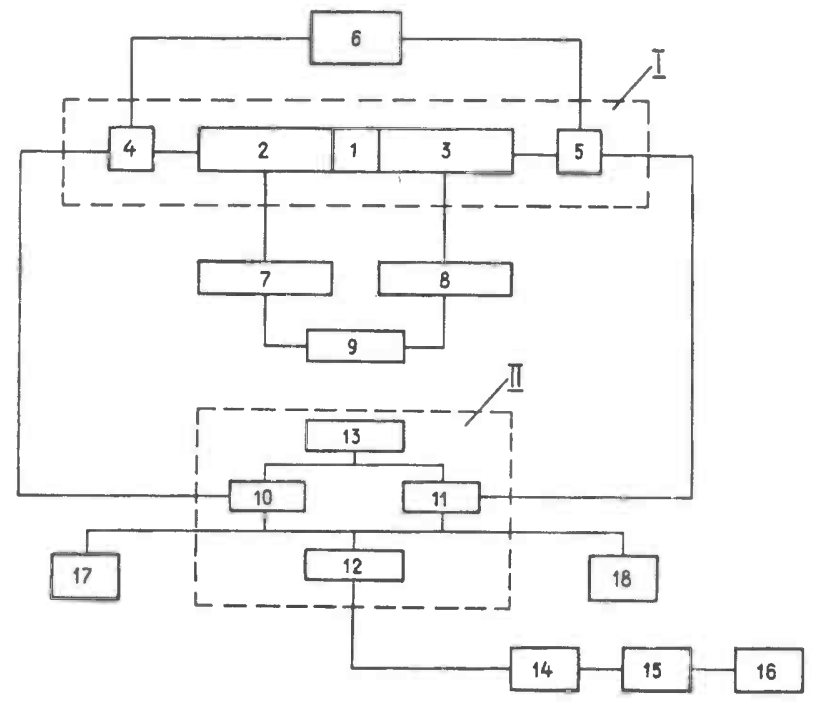

Fig. 1. Block diagram of the liquid scintillation system: I: ${ }^{14} \mathrm{C}$ activity detector unit; 1 . vial; 2 , 3. photomultipliers FEU-97; 4, 5. preamplifiers; 6. pulse generator TE-110A; 7, 8. high-voltage power supply units VS-22; 9. electronic stabilizer T-2000. II: Amplitude analyzer unit; 10, 11. amplitude analyzers; 12 . double coincidence and anticoincidence unit; 13 . power supply unit; 14. recounting instrument $\mathrm{PP}-15 \mathrm{~A} ; 15$. counter ZUM-23; 16. automatic printing unit BAP-3; 17-18. recounting instruments PSO-2-4

\section{WEST AND NORTHWEST SIBERIA}

There are three separate geocryological zones in the northwestern Siberian Plain (Baulin et al. 1967), characterized by temperature regime, thickness, cryological and geological structure and freezing, and cryolithogenic structures. Syngenetic permafrost is typical only for the northern geocryological zone. A distinctive feature of this area is the presence in deposits, starting from the Kazantsev Age, of interlayers of ground ice, the genesis of which has been widely discussed (Baulin 1972; Danilov 1987b).

In 1977-1978, E. G. Karpov (1980), of the Igarka Permafrost Station, investigated a glacial deposit on the subflood terrace of the Yenisey River $\left(71-72^{\circ} \mathrm{N}\right), 40 \mathrm{~km}$ southwest of Innokentievsky. At altitude $20 \mathrm{~m}$ asl, the outcrop, Tab-Sel, was presumably of Kargin age. Tab-Sel lies under a thick layer $(10 \mathrm{~m})$ of varved clays (Fig. 2), which formed under subaquatic conditions in a freshwater reservoir. Gradual epigenetic freezing occurred as the area grew drier. E. G. Karpov (1980) 


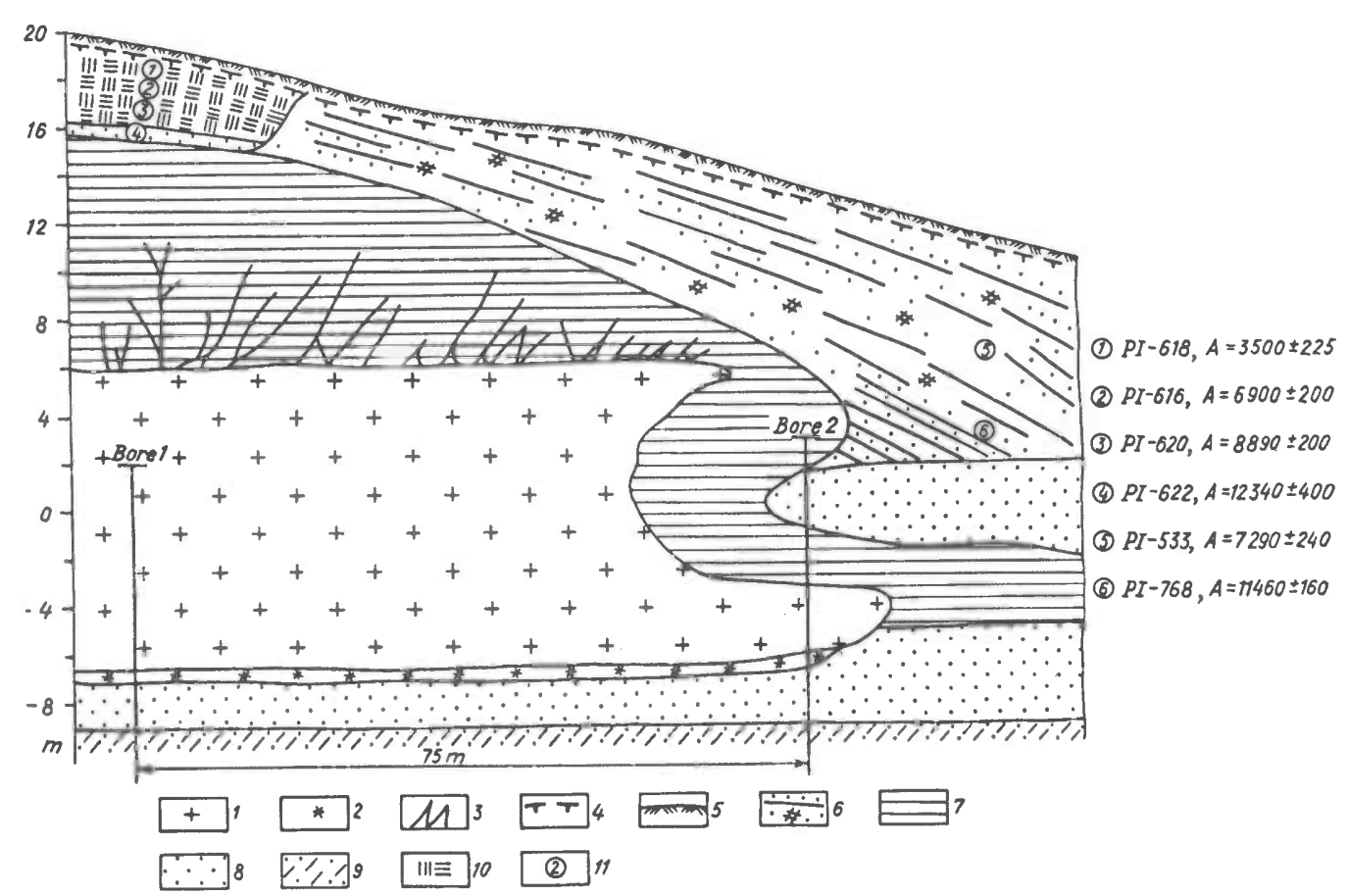

Fig. 2. The northeastern margin of the Tab-Sel outcrop (according to Karpov 1980): 1. ground ice sheet; 2 . cavity with deep hoar-frost; 3 . cracked ice; 4 . upper boundary of the permafrost; 5 . moss-vegetation tundra cover; 6 . layered sands with vegetal detritus; 7. ribbon clay; 8 . sand; 9 . loam; 10 . peat; 11 . sampling sites.

suggested that such freezing of varved clays is a result of injections of pressure waters. Formation of the varved clays is estimated at $4.5 \mathrm{ka}$. The terrace is covered with a peat bog up to $3 \mathrm{~m}$ thick. Samples of wood and peat dated as old as $12,340 \mathrm{yr}$. Thus, permafrost covering the ice sheet could have formed over 16-17 ka ago.

Karpov (1980) discovered another outcrop of ground ice, Ledyanaya Gora, or Ice Mountain, on the right bank of the Yenisey River near the Polar Circle, $100 \mathrm{~km}$ south of Igarka, Siberia. It has also been described by Danilov (1987b) and Grigoryev and Karpov (1982). The ice-sheet deposit, 20-30 m thick, overlies the subflood Eargin terrace and underlies till that is composed of an upper layer without boulders and a lower layer of many erratic boulders, separated by a small sand interlayer (Fig. 3). In some places, 4-6-m-thick peatbogs underlie the terrace surface. We obtained two ${ }^{14} \mathrm{C}$ dates for these peat deposits: $1400 \pm 30$ : PI-435 and $4013 \pm 100$ : PI-431; these results confirm four dates that we subsequently obtained at our laboratory: PI-819 to PI-822 (Table 1). The results indicate that thermokarst developed on the terrace surface during the Late Pleistocene. Modern lodgment was also dated in the thermokarst slope deposits by samples PI-154, -389, -411 and -755 .

We dated plant remains from sand and pebble deposits at a depth of $15 \mathrm{~m}$. Results showed the same ages of $>36,000$ for PI- $818,-844$ and -843 (Table 1). Similar data were obtained at the Geological Institute, Moscow (43,000: GIN-1894; 50,000: GIN-1892) (Sher and Plakht 1988). Table 1 lists all ${ }^{14} \mathrm{C}$ dates available for the Ice Mountain outcrop, which attribute it to the Early Zyryanskaya stage of the last glaciation. 


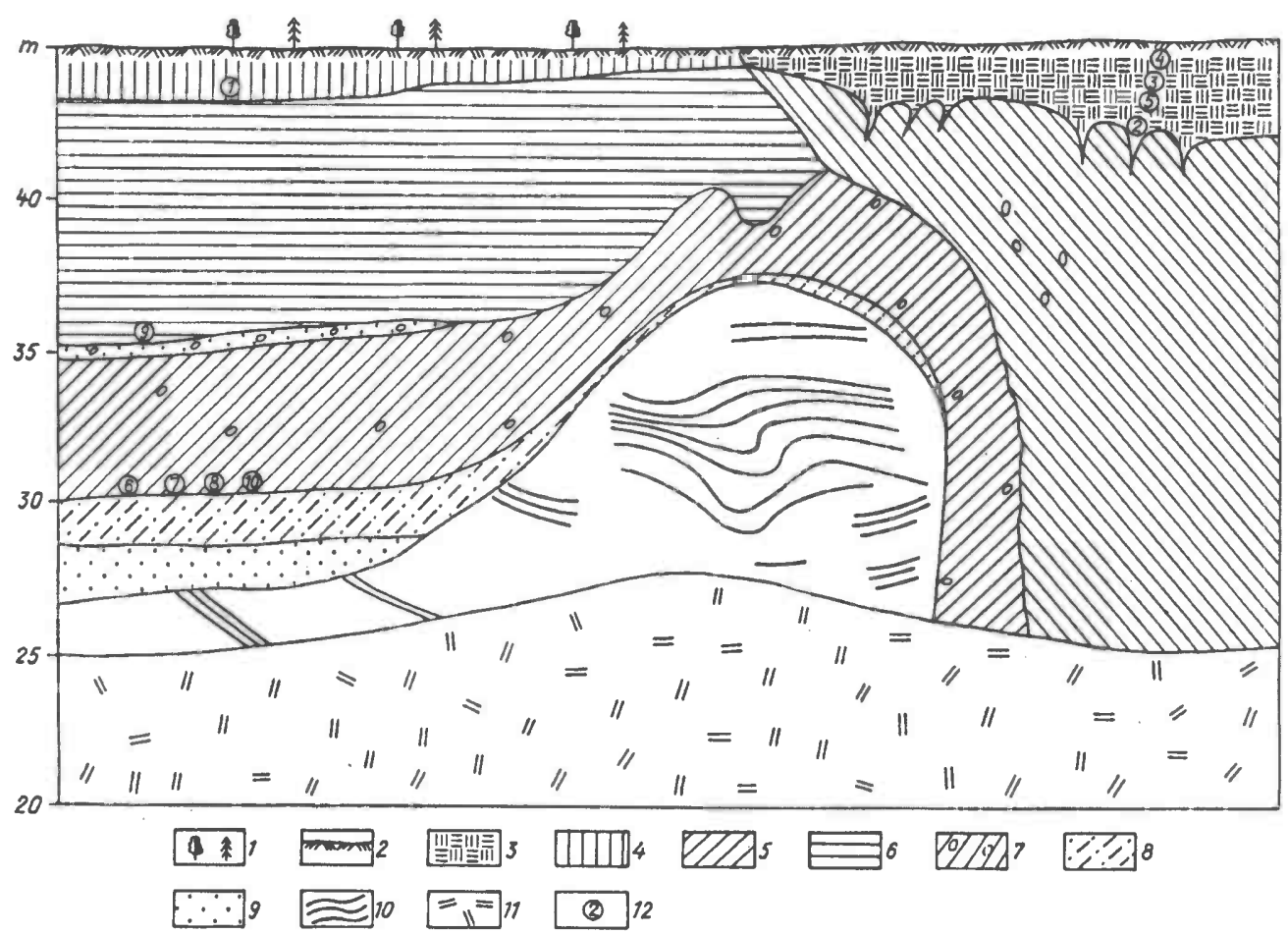

Fig. 3. The northern "dome" of the ice sheet of the Ledyanaya Gora outcrop (Karpov 1980): 1. mixed northern taiga forest; 2. moss cover; 3 . peat; 4. cover loam; 5. lake loam; 6 . loam without bolders; 7. loam with boulders; 8 . ribbon-layered loam; 9. fine-grained sand; 10 . interlayers of soil in ice; 11 . slope deposits; $12 .{ }^{14} \mathrm{C}$ samples.

TABLE 1. Radiocarbon Dates from Ledyanaya Gora

\begin{tabular}{lllcc}
\hline Sample no. & Sample location & Sample material & $\begin{array}{l}\text { Sampling } \\
\text { depth }(\mathrm{m})\end{array}$ & ${ }^{14} \mathrm{C}$ age \\
\hline GIN-1893* & Cover loam & Wood fragments & 1.5 & $1270 \pm 100$ \\
PI-819 & Peat & Wood fragments & 4.97 & $3570 \pm 210$ \\
PI-820 & Peat & Peat & 2.65 & $4295 \pm 190$ \\
PI-821 & Peat & Peat & 1.0 & $3720 \pm 240$ \\
PI-822 & Peat & Wood & 3.8 & $3000 \pm 225$ \\
PI-818 & Water-glacial sand-pebbles & Plant remains & 15.0 & $>36,000$ \\
PI-844 & Water-glacial sand-pebbles & Peat & 14.0 & $>36,000$ \\
PI-845 & Water-glacial sand-pebbles & Plant remains & 15.0 & $>36,000$ \\
GIN-1894 & Sandy interlayer & Wood remains & 9.0 & $43,100 \pm 1000$ \\
GIN-1892 & Boulder loam & Wood remains & 14.0 & $>50,000$ \\
\hline
\end{tabular}

*GIN samples submitted by Yu. B. Fainer; PI samples submitted by E. G. Karpov

${ }^{14} \mathrm{C}$ results were also obtained from a section near the Igarka Permafrost Research Station (NIMS), located on the floodplain of the Igarka River $750 \mathrm{~km}$ from the Igarka Channel. To a depth of 19.5 $\mathrm{m}$, this outcrop shows a profile of varved clays with well-delineated cryogenic structure-ice striae and large buried ice layers-indicating a segregation ice formation and fixing the process of 
freezing and formation of varved clays. Quaternary deposits in the area are represented by "sanchugov sea loams, sands of Kazantsev age, gravel-pebble loams and supes of the Zyryansky glaciation, and by lacustrine glacial varved clays covered from the surface by Kargin sands" (Zhestkova 1978).

The mixed character of sedimentation provides further evidence of the unique profile of freezing and ice formation processes in ribbon clays. ${ }^{14} \mathrm{C}$ dates on wood from a layer of ribbon clays showed mostly outlying ages (Table 2), which characterize the evolution of the region's permafrost in the Late Pleistocene.

TABLE 2. ${ }^{14} \mathrm{C}$ Dates from Igarka, Siberia

\begin{tabular}{lllcc}
\hline $\begin{array}{l}\text { Sample } \\
\text { no.* }\end{array}$ & Location of sample & $\begin{array}{l}\text { Sample } \\
\text { material }\end{array}$ & $\begin{array}{l}\text { Sampling } \\
\text { depth }(\mathrm{m})\end{array}$ & ${ }^{14}$ C age \\
\hline PI-787 & Kureika River valley second rapids & Tree trunk & 0.9 & $2200 \pm 230$ \\
PI-788 & Igarka River floodplain terrace, at NIMS station & Wood & 1.1 & $2117 \pm 100$ \\
PI-789 & Igarka River floodplain terrace, at NIMS station & Wood & 8.3 & $>36,000$ \\
PI-790 & Igarka River floodplain terrace, at NIMS station & Wood & 8.2 & $>36,000$ \\
PI-791 & Igarka River floodplain terrace, at NIMS station & Wood & 7.7 & $>36,000$ \\
PI-792 & Igarka River floodplain terrace, at NIMS station & Wood & 8.2 & $>36,000$ \\
PI-794 & $\begin{array}{l}\text { Floodplain terrace of the Yenisey River, in the } \\
\text { area of the Igarka River NIMS station }\end{array}$ & Wood & 7.5 & $>36,000$ \\
\hline
\end{tabular}

*Samples submitted by O. A. Kazansky

\section{NORTH YAKUTIA}

Coastal lowland North Yakutia exhibits cryogenic and geological features of permafrost formation that persisted throughout most of the Pleistocene. Subaqueous permafrost in North Yakutia is due largely to a shelf zone of both the Laptev and East Siberian Seas. Marine transgressions and regressions occurred during the Late Pleistocene, caused by a relative change in sea and land levels. This led to flooding or drying of terrestrial surfaces and produced a peculiar temperature and hydrogeological regime. Coastal displacement during the Late Pleistocene occurred as a result of a complex interaction of tectonic and glacio-isostatic movements and global sea-level changes.

${ }^{14} \mathrm{C}$ dates were obtained from basal sediments of the Sannikov Strait, which connects Maly and Bolshoi Lyakhovsky Islands in the East Siberian Sea (Fig. 4). Pleistocene coastal-maritime sediments, lenses of pebbles and relatively deep-water sediments (clay, clayey aleurites) lying at the base of pre-Cenozoic and paleogenic layers were submitted by Fartyshev (1978). ${ }^{14} \mathrm{C}$ dates were obtained from clay and clayey aleurites on samples

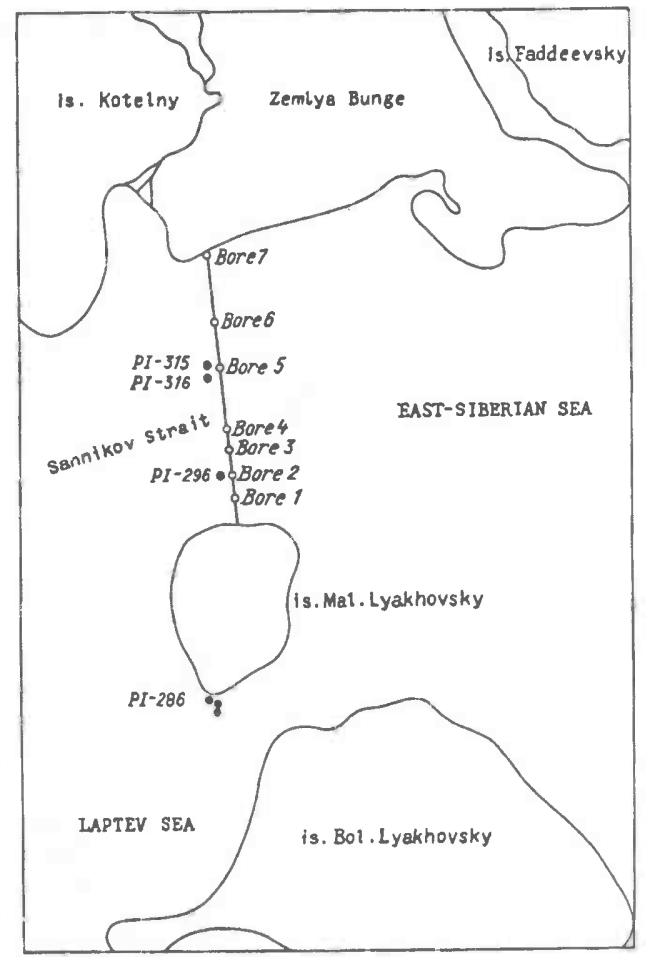

Fig. 4. Area of regional geocryological investigations (1974-1978) by A. I. Fartyshev, Laboratory for Thermal Physics of Cryogenic Phenomena, Permafrost Institute 
of plant detritus at depths of 28 and $32 \mathrm{~m}$, respectively. The results were beyond the ${ }^{14} \mathrm{C}$ dating limit (PI-315: 36,000; PI-316: 45,000).

The basal relief of the strait, from south to north, shows steep "steps" that seem to correspond to different levels of the Late Pleistocene coastline. On one step, $c a .20 \mathrm{~m}$ high, in the southern part of the strait, an aleurite sample (plant detritus) was taken at a depth of $12.2 \mathrm{~m}$. It dated to 10,250 \pm 270 (PI-286). PI-286 (6335 \pm 220$)$ was obtained for basal sediments of the Laptevs Sea from clayey aleurites at a depth of $3.99 \mathrm{~m}$. These samples were obtained from permafrost, as confirmed by cryotexture analysis (Fig. 5). Geochronological data for eroded shelf sediments were reported by S. V. Tomirdiano (1980).

The subaerial permafrost zone of the coast is represented by perennially frozen deposits. From a comparison of profiles of alas deposits with ${ }^{14} \mathrm{C}$ dates obtained from them, Kaplina and Lozhkin (1979) conclude that alases of north Yakutia generally formed 11-12 ka ago, during the Late Artan warming. Sher and Plakht (1988) and Kaplina and Lozhkin (1982) assign the chronological development of the ice complex in this region to the last $50 \mathrm{ka}$. As an example, Table 3 lists ${ }^{14} \mathrm{C}$ dates from a core of the Mamontov-Khayott ice complex, Bykovsky peninsula, Lena River delta. These data correlate with results reported by Kaplina and Lozhkin (1982) and Tomirdiaro, Arslanov and Chernenkiy (1984).

\section{Central yakutia}

Ice-containing permafrost has existed throughout Central Yakutia since the mid-Middle Pleistocene (Katasonov and Ivanov 1973). Permafrost thickness depends upon the composition and ice content

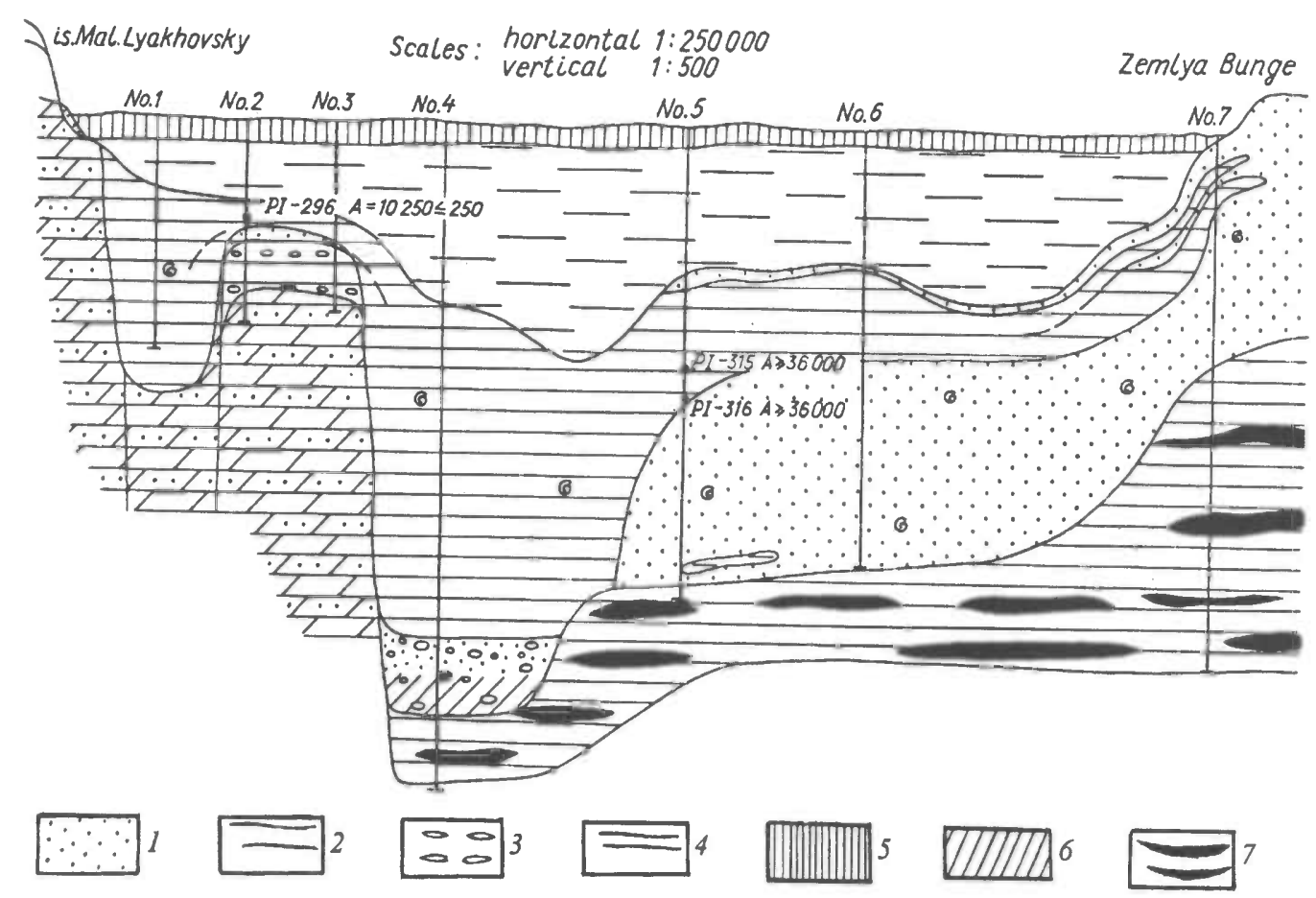

Fig. 5. Geological structure of the Sannikov Strait and sampling sites: 1. sand; 2. clay; 3. pebbles; 4. water; 5. ice; 6. sandy aleurite; 7 . coal. 
TABLE 3. ${ }^{14} \mathrm{C}$ Dates of the Mamontov-Khayott Outcrop

\begin{tabular}{llllll}
\hline Sample no. & Sample location & Sample material & $\begin{array}{l}\text { Sampling } \\
\text { depth }(\mathrm{m})\end{array}$ & ${ }^{14} \mathrm{C}$ age & Collector \\
\hline PI-750 & Lena River delta & Peat & 2.5 & $2925 \pm 100$ & Slagoda \\
PI-751 & Bykovsky Peninsula & Peat & $8.5-9.4$ & $15,100 \pm 1600$ & Slagoda \\
PI-749 & Outcrop & Plant detritus & 15.0 & $20,835 \pm 500$ & Slagoda \\
PI-752 & Mamontov- & Peat & $16.0-17.0$ & $22,000 \pm 1600$ & Slagoda \\
PI-748 & Khayott & Peat & 20.0 & $22,200 \pm 930$ & Slagoda \\
PI-497 & & Peat & 22.0 & $>45,000$ & Fartyshev \\
PI-499 & & Peat & 31.5 & $>45,000$ & Fartyshev \\
Lu-1328* & & Mammoth bone & 17.0 & $21,630 \pm 240$ & Tomirdiaro \\
Lu-1263 & Grass & 18.0 & $22,070 \pm 410$ & Tomirdiaro \\
Lu-1329 & Peat & 20.0 & $28,500 \pm 1630$ & Tomirdiaro \\
Lu-1330 & & Peat & 22.0 & $33,040 \pm 810$ & Tomirdiaro \\
SOAN-2294** & & Moss and grass & 20.0 & $29,920 \pm 365$ & Kunitsky \\
\hline
\end{tabular}

${ }^{*} \mathrm{LU}=$ Institute of Geographical Research, St. Petersburg; samples dated by Kh. A. Arslanov

**SOAN = Institute of Geology and Geophysics, Novosibirsk; sample dated by L. Orlova

of the ground, averaging 300-350 m; maximum thickness ranges from 500 to $600 \mathrm{~m}$ in the fluvioglacial plain of west Priverkhoyanie.

On the sedimentary surface of the alluvial plain, for which most of the ${ }^{14} \mathrm{C}$ data were obtained, floodplain and floodplain terraces have been identified. Terrace deposits ranging in age from Holocene to the Middle Pleistocene formed under permafrost conditions and contain ground ice. This laboratory's geochronological investigations cover northeastern central Yakutia (between the Lena and northern Amga Rivers and the Lower Aldan valley), and the left shore of the Lena River.

Naturally occurring bare Aldan River terraces frequently exhibit surface ground ice with clearly identifiable cryogenic textures or other signatures of permafrost. These outcrops make it possible to study formation properties of permafrost and their freezing conditions. ${ }^{14} \mathrm{C}$ dates were obtained for terrace levels of the Lower Aldan with relative marks of 50,30,15-20 and $10 \mathrm{~m}$. In the area between the Lena and the Amga Rivers, complex geochronological and cryolithological studies were made of alas deposits and alas land forms (Katasonov 1979).

The aim of this study was to observe alas depressions in different stages of development within different-aged terraces. The age of the alas terrain was studied in interalas areas and in deposits of alas depressions. Through ${ }^{14} \mathrm{C}$ dating, two ice complexes of different ages were identified for the central Yakutia lowland. Figure 6 shows a section of the Mamontova Gora (Mammoth Mountain) outcrop located on the left bank of the Aldan River, $c a .300 \mathrm{~km}$ from the mouth. The section is located at the $50-\mathrm{m}$ flood terrace of the river, corresponding to the Abalakh level of the accumulative plain in the central Yakutia lowland, according to Soloviev's (1973) classification. ${ }^{14} \mathrm{C}$ dates of the ice complex of the Abalakh surface reveal an age beyond the limits of the method $(>56 \mathrm{ka}$ ) and $2300 \mathrm{ka}$, according to TL dates.

The absolute age of the ice complex of the Tyungyulyunskaya surface of the accumulative plain of central Yakutia (relative altitude $70-100 \mathrm{~m}$ above the river level) is $c a .20-25 \mathrm{ka}$. Figure 7 is a profile of the shore precipice of thermokarst Lake Yener between the Lena and the northern Amga. ${ }^{14} \mathrm{C}$ dates for several mature alas depressions in the same area, including Ebe, Khara Bulgunnyakh and Myuryu, do not exceed $12 \mathrm{ka}$. For more results on the ages of leading elements of the alas terrain, see Katasonov (1979) and Kostyukevich (1985). 


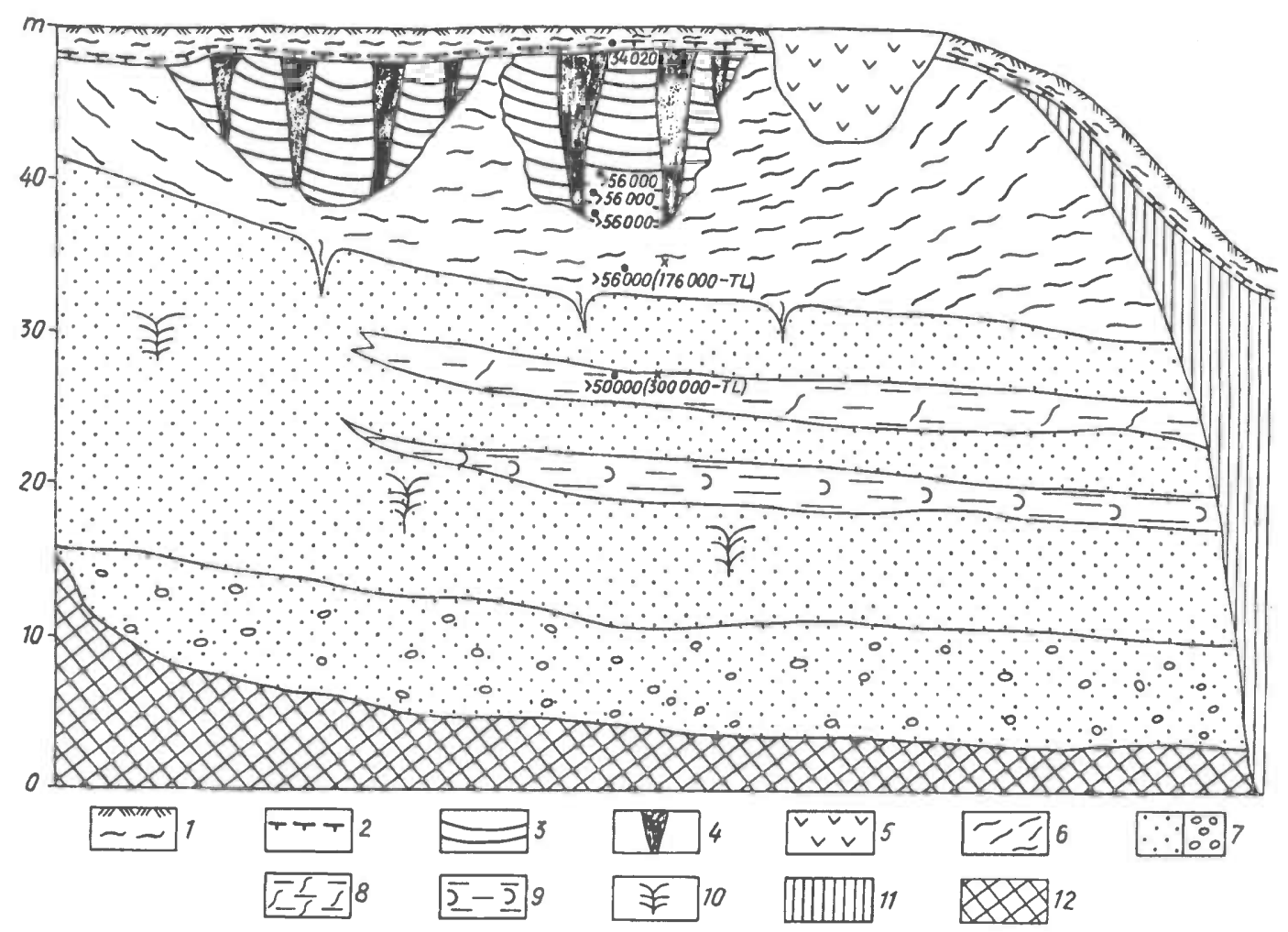

Fig. 6. Permafrost-geological profile of the 50-m terrace of the Aldan River, Mamontova Gora outcrop: 1. deluvial cover; 2. depth of active layer; 3 . brown-gray loams with grass and shrub roots-sedimentary positions are poorly defined; 4 . ice vein; 5. thermokarst; 6. horizontally layered bluish-gray loam; 7. alluvial sands and pebbles; 8 . alluvial loam with wood remains; 9. peaty loam with latticed cryotextures; 10 . soil veins; 11 . deposits of adjacent $30-\mathrm{m}$ terrace; 12 . neogenic sands.

\section{WEST YAKUTIA}

West Yakutia, located within the watershed surfaces of the trap plateau, exhibits a wide range of closed lake depressions, the origins of which have not yet been ascertained. Lake deposits in permafrost lie directly on mother rock; this feature of lake depressions in West Yakutia distinguishes them substantially from alas deposits of Central Yakutia, for which cryological and geological properties of their development are well known.

${ }^{14} \mathrm{C}$ dates were obtained for Kuba-Tyuyusteekh and Bero, located $70 \mathrm{~km}$ northeastward of Chernyshevsky. The ground at the bottom of these lake depressions is frozen. The upper 3-4 m consists of peat, which overlies a loam layer of aqueous origin. The base of the profile includes tuff cemented by basal ice. The total deposit is $c a .15 \mathrm{~m}$ thick (Spesivtsev 1978). Tuff samples were taken from depths between 1.5 and $4 \mathrm{~m} .{ }^{14} \mathrm{C}$ dates (PI-365: $8155 \pm 90$; PI-367: $8895 \pm 250$; PI207: $9500 \pm 200$ ) indicate a Holocene age for the peat.

\section{CONCLUSION}

The comprehensive study of permafrost sections in northern Eurasia enabled us to date the separate stages in the development of cryogenic processes. The data obtained allow us to correlate climatic events during the Late Pleistocene with global and regional time scales. 


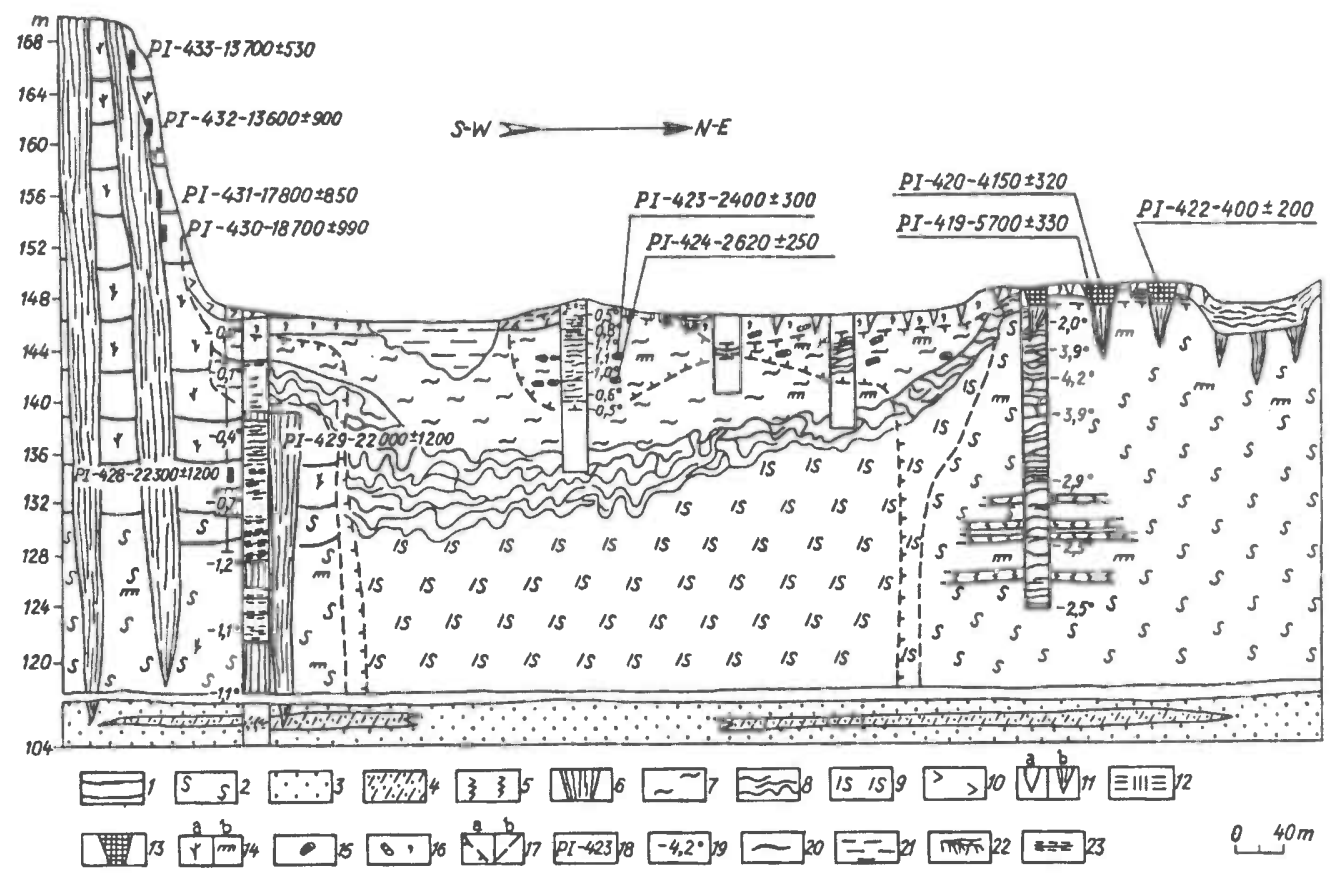

Fig. 7. The cryolithological profile of the middle part of Yener alas depression: 1 loam and supe with old wedge ice; 2. ancient lake deposits and ice-saturated silt; 3 . sand; 4. overlapping sand and supe; 5. microdisplacement in old deposits; 6. wedge ice; 7. bluish-gray deep-water silt; 8. thermocollapsive deposit; 9. old lake deposit: silt subsided during midMiddle Pleistocene (MMP) thawing; 10. loam on slopes and on removal cones; 11. present cryogenic formation; a. soil vein; b. soil wedge with ice layers in MMP; 12. peat; 13. pseudomorphs on old ice veins; 14 . a) grass roots; b) vegetal detritus; 15. leaves of aqueous grass; 16. reeds; 17a. MMP boundary; 17b. MMP boundary at maximum development of talik beneath lake; $18 .{ }^{14} \mathrm{C}$ dates; 19 . temperature; 20 . boundary of lithological type; 21 . cryogenic lens-like texture; 22 . lensshaped; 23. net-like, belt-like

\section{REFERENCES}

Arslanov, Kh. A. and Gromova L. I. 1968 Geokhimiya 2: 218-224.

Baulin, V. V. 1972 Questions of the formation of sheet deposits of ice in the Yaman Peninsula. In Geocryological and Hydrogeological Investigations in Siberia. Yakutsk.

Baulin, V. V. et al. 1967 Geocryological Conditions of the West Siberian Lowland. Moscow, Nauka.

Danilov, I. D., 1987a The history of development of the permafrost zone of the northern part of Eurasia in the Late Cenozoic. In Geocryological Investigations. Yakutsk: 46-51.

1987b The problem of genesis of sheet deposits of ground ice. In Geocryological Investigations. Yakutsk: 176-182.

Fartyshev, A. I. 1978 On the dynamics of the permafrost zone of the shores of the Sannikov Strait. In Geocryological and Hydrogeological Investigations. Yakutsk: 16-22.
Grigoryev, N. F. and Karpov, E. G. 1982 Toward the origin of the sheet deposit of ground ice on the Yenisey River at the Arctic Circle latitude. In Ground Ice, Yakutsk: 17-25.

Kaplina, T. N. and Lozhkin, A. V. 1979 The age of alas deposits of the coastal lowlands of Yakutia. Izvestiya Akademii Nauk SSSR, Seriya Geologicheskaya 2: 169-172.

1982 The age of the ice complex of the coastal lowlands of Yakutia. Izvestiya Akademii Nauk SSSR, Seriya Geologicheskaya 2: 16-19.

Karpov, E. G. 1980 Ground Ice of the Yenisey North. Nauka, Siberian Division.

Katasonov, E. M. 1979 Structure and Absolute Geochronology of Deposits of Central Yakutia. Novosibirsk, Nauka, 95 p.

Katasonov, E. M. and Ivanov, M. S. 1973 Cryolithology of Central Yakutia. Guidebook. Yakutsk. 
Kostyukevich, V. V. 1985 Scientific-methodical peculiarities of radiocarbon dating of Late Pleistocene permafrost deposits of central Yakutia. In The Evolution of the Permafrost Zone of Eurasia in the Late Cenozoic. Moscow, Nauka.

Sher, A. V. and Plakht, I. R. 1988 Radiocarbon dating and problems of Pleistocene stratigraphy of the plains in the northeast of the USSR. Izvestiya Akademii Nauk SSSR, Seriya Geologicheskaya 2: 16-20.

Shilo, N. A. and Tomirdiaro, S. V. 1982 Paleography and absolute geochronology of the Late Pleistocene in the northeastern part of Siberia. In Cryogenic and Geological Processes and Paleography of the Lowlands of Northeastern Asia. Magadan: 170-181.

Soloviev, P. A. 1973 The Alas Thermokarst Terrain of Central Yakutia. Guidebook. Yakutsk.
Spesivtsev, V. I. 1978 Deposits of Lake Depressions on the Trap Plateau of West Yakutia. In Geocryological and Hydrogeological Investigations. Yakutsk: 75-81.

Tomirdiaro, S. V. 1980 The Loess-Ice Formation of East Siberia in the Late Pleistocene and Holocene. Nauka, Moscow, 183 pp.

Tomirdiaro, S. V., Arslanov, Kh. A. and Chernenkiy, B. I. 1984 New data on the formation of loess-ice deposits in North Yakutia and habitation conditions for mammoth fauna in the Arctic in Late Pleistocene. Doklady Akademii Nauk SSSR 278(6): 416-419.

Velichko, A. A. 1968 Natural Processes in the Pleistocene. Moscow, Nauka.

Zhestkova, T. N. 1978 On the cryogenic structure of ribbon clays. Meralotnye Issledovaniya 17: 5-12. 